\title{
The Development of E-Worksheet Using Kvisoft Flipbook Maker Software Based on Lesson Study to Improve Teacher's Critical Thinking Ability
}

\author{
https://doi.org/10.3991/ijim.v15i01.15679 \\ Maria Erna $\left.{ }^{\bowtie}\right)$, Elfizar \\ Universitas Riau, Pekanbaru, Indonesia \\ mariaerna@lecturer.unri.ac.id \\ Citra Ayu Dewi \\ Universitas Pendidikan Mandalika, Mataram, Indonesia
}

\begin{abstract}
Critical thinking is an essential educational aspect. Future success requires the ability to think critically. Based on the findings, the ability of teachers to think critically was still low. If no solution sought, the quality of graduates would be affected. One way to improve the quality of learning is by using eworksheet using kvisoft flipbook maker software based on lesson study. The lesson study was chosen because it was able to develop critical thinking. This study aimed to develop an e-worksheet using kvisoft flipbook maker software based on lesson study to improve teacher's critical thinking ability. This study used is 4-D model namely Define, Design, Develop, and Disseminate. The study subjects were 63, included chemistry teachers and students of class XI SMA in Rokan Hulu, Riau, Indonesia. The data collection used expert validation questionnaires to determine the feasibility of the e-worksheet that has developed and test instruments to measure critical thinking ability. The data were analyzed using descriptive statistics assisted by SPSS 23 version and N-Gain Formulation. Based on the result, the e-worksheet using kvisoft flipbook maker software based on lesson study is feasibility with very decent category and reliability of the critical thinking instrument with very high criteria. Teachers' and student's critical thinking ability increased from cycle I until cycle III with category good and very good. This means that the development e-worksheets using kvisoft flipbook maker software based on lesson study was effective in improving critical thinking ability of teachers' and students.
\end{abstract}

Keywords-E-worksheet, lesson study, critical thinking

\section{Introduction}

Critical thinking is popular among researchers [1] [2], an individual can enhance his ability to solve problems with critical thinking [3]. Critical thinking skills are an important part of education [4], because success is required when students are outside 
school [5] [6], students can clarify, think deeply and become problem-solvers in social life [7].

Critical thinking has become a norm; the main focus of learning. Curriculum authorities in many developed countries have put critical thinking skills in their curriculum as learning objectives 14, and educational standards such as in the United States, Canada, Europe, Australia, and New Zealand [7] [8]. In pair with it, Howard et al. [9] stated that critical thinking is important because it helps students to solve challenges efficiently and to make a positive contribution to society. Critical thinking belongs to important and influential skills as it is necessary for each person in corporate leadership, decisionmaking, professional achievement, and clinical judgment [10]. Therefore, critical thinking is an important skill that students need to learn and train [11].

Based on observations conducted showed that teachers' critical thinking ability still low. In contrast, teachers must be able to meet the mandate of teaching critical thinking for students as a frontier of education. Nevertheless, based on the preliminary study conducted, it revealed that senior high school's critical thinking ability in Rokan Hulu, Riau, Indonesia is still at a low level. Further, the proof showed that the test score of critical thinking on the scale of $0-100$, obtained the average score is 21.89 . The questionnaire indicates that the critical thinking capacity of students is because teacher-led learning methods are still focused around teachers, where teachers dominate the school process and students do not have a good chance to grow independently through exploration and processes [12]. Teachers teaching with this method will contribute to the accumulation of knowledge and are difficult to achieve [5] [6]. Thus, Teachers are expected to plan learning well to train students' critical thinking skills. This shows that teachers' critical thinking skills need to be developed so that the critical thinking skills of students increase.

Critical thinking is a process of acquiring new knowledge through problem-solving and collaboration [13]. Critical thinking focuses on learning and provides students with opportunities to learn through exploration [14]. Critical thinking skills also concentrate on reflective thinking and what to believe and do [9] [10]. The term critical thinking often describes competence and can be applied in teaching and learning processes. It is always used in research references to describe reflection, focus on tasks and beliefs [11]. Specifically, critical thinking skills involve learning science as follows: (1) classifying, (2) assuming, (3) predicting and hypothesizing, (4) interpreting data, differentiating or making conclusions, (5) measuring, (6) designing an investigation to solve the problem, (7) observing, (8) making a graph, (9) reducing the probability of experimental error, (10) evaluating, (11) analyzing [12]. Various types of learning models used can improve critical thinking skills for students and teachers have been reported by Zhou et al. [16]; Qing et al. [17]; Espinosa et al. [18].

Critical thinking can be improved by learning. A suitable learning model is necessary for a learning process to enhance critical thinking ability. One learning model that can enhance critical thinking ability is Lesson Study. Lesson study is a systematic process for testing the effectiveness of teaching for teachers to improve critical thinking capacities [20]. Stages of the lesson study included plans, do, and see [19]. Recently, learning models based on lesson study have been successfully reported to improve learning outcomes of students [20] [21] [22], to develop pre-service teachers' capacity in teaching 
science [23] [24], to increase critical thinking skills [25], to enhance mathematics teachers' quality [26], to improve chemistry teacher competency [27] and to build students' character [28].

In each learning, including lesson study, teachers must use learning tools [28] [29][30]. One of the learning devices used is an e-worksheet using kvisoft flipbook maker software. E-worksheet is needed because the worksheet used in learning is usually paper-based all this time, so the costs incurred are large; students quickly get bored and less use technology development. An interactive worksheet is needed, so students don't get bored quickly. Also, it can save costs. Therefore, an electronic worksheet needs to be developed (E-Worksheet). Later, E-Worksheet is designed for use with laptops, PCs, smartphones, and tablets to display writing, picture, sound, video, and interactive so that it is attractive to students. Students are also used to using computer and gadget technologies in learning, making e-worksheet easy to accept. With this easy access, students are hoped to learn more flexibly [4]. Smart mobile devices as tablets have made dynamic entrances in education [58].

The E-Worksheet is one of the ways to enrich students' mastery of the material [31] [32]. E-worksheets also promote teaching and learning activities such that positive connections between students and teachers can improve student learning outcomes. The details, tasks and activities relevant to the content given are broken down in the e-worksheet [30]. This initiative is intended to instruct students in different activities. Moreover, students must be more interested in discussing various topics [4]. Practices are one of the motivating factors for student learning and play a crucial role in promoting student achievement [28]. On the other hand, [33] [34] state that the practice can investigate direct symptom and scientific method observation details.

Worksheets include activities that are suitable for the subject being learned and used to aid in the achievement of learning objectives. It's a guide to solving a problem for the student [38]. In general, some important parts of worksheets are used as student focus. This section can help students increase their learning stimulus, such as a brief description of the topic, instructions for learning activities and questions, exercises, questions, and conclusions [36]. Furthermore, worksheets are used as a guide to assist learning activities in school and outside the school environment by assigning tasks to specific items, and students focus on solving problems in the studied material [41]. Several studies have developed electronic worksheets that are suitable for use in the learning process so can be improve learning outcomes and critical thinking [35] [36] [37] [38] [39].

Worksheets for the study of chemistry in the thermochemistry material are printed forms of work. Such teaching content is not designed to meet students' needs. Printed worksheets are typically insightful and attractive and cannot reveal the idea they convey, sound, video, animation, and images. Most students are more interested in instructional materials that are used in printed sheets with other equipment such as computers/ Laptops or even smartphones [29]. Therefore, the print worksheet must be updated in software or programs with one ICT product. Also, using e-worksheets, students' views can be modified to read, understand and relax as e-worksheets include photos, narratives and graphics. However, e-worksheets which contain various features such as audio, music, animation and video [30]. One software used to convert print worksheets as 
a flipbook is kvisoft flipbook manufacturer. The software application flipbook developer supports in learning because it is not only written, but also included with the action, videos and audio, allowing immersive learning media to become more than monotonous [28]. Studies have shown that when computers are used in developmentally appropriate ways [62] in education, new opportunities for understanding concepts and processes open [60] and enhance students' conceptual and procedural knowledge while improving the critical thinking [52] [54] [55]. These reduced cognitive demands should increase attention to content, and potentially promote greater and more immediate learning with mobile tablet devices [58] [61].

Therefore, this study aims to develop an e-worksheet using kvisoft flipbook maker software based on lesson study to improve teachers' critical thinking ability. Formulation of research problem are 1) How is the feasibility of e-worksheet using kvisoft flipbook maker software on thermochemistry material? 2) Is there improving teachers' and students' critical thinking ability after implemented e-worksheet based on lesson study?

\section{$2 \quad$ Literature Review}

\subsection{Kvisoft flipbook maker}

Kvisoft flipbook maker is a program for a book or book show other teaching material in the form of a photobook in a book/digital electronic worksheet. The software is free to download through internet connection [53]. The Kvisoft Flipbook Maker is a media for converting the PDF document into a digital publication, seen as a varied, creative and productive digital magazine. This program not only offers a lecture but also develops immersive learning, as students take part in a learning experience on prepared displays. Kvisoft flipbook maker can be the answer for learning media, so it supports the statement "the concepts that can be implemented are to use computer-based media in the learning process" [56]. A Kvisoft flipbook maker is an electronic learning worksheet program. Worksheet is a content developed for learning independently by students. Worksheet is considered an individual learning media because it provides instructions for self-study [57]. This means that the user of the worksheet will make the learning process without the teacher being present directly.

\subsection{Lesson study}

Lesson studies are investigations carried out by a team of teachers based on an actual classroom lesson to research and enhance teaching on a specific subject [63]. Study lessons are real lessons taught by the students themselves, that is: a) a particular problem created by the instructor, purpose or vision of pedagogical practice; (b) carefully designed, usually with one or more of their fellow students; (b) observed in other teachers; (d) registered for review and reflection; and (e) the lesson group members, other colleagues, administrators and/or invited commentators [64]. During the research lesson, team members collect data on student thought and learning, study selected students to see how their thought progresses (or fails to evolve), and what aspects of lesson design improve or hinder learning [65]. By teaching the teachers work together to research 
lessons and make meaningful improvements in teaching and learning. Thus, teachers can face challenges or differences that inspire them to discover, test and analyze responses inside socially collaborative environments [66].

\section{$3 \quad$ Methodology}

Researchers have conducted discussions and workshops to prepare e-worksheets using kvisoft flipbook maker software based on lesson study on thermochemistry material which takes approximately six months. This research used is 4-D model has 4 phases are Define, Design, Develop, and Disseminate. The 4-D model is a structured approach to the planning and design processes with a standardized structure to ensure that their products are competitive and efficient [30]. In this study, E-Worksheet has received input from three (3) lectures who are specialists in chemical education and three (3) teachers in IT with the evaluation criteria as in table 1 below.

Table 1. Validation of Criteria

\begin{tabular}{|c|l|l|}
\hline Interval & \multicolumn{1}{|c|}{ Qualification } & \multicolumn{1}{c|}{ Category } \\
\hline $81-100$ & Very good & Very Decent \\
\hline $61-80$ & Well & Worthy \\
\hline $41-60$ & Enough & Worthy enough \\
\hline $21-40$ & Less & Not feasible \\
\hline $0-20$ & Very less & Very inadequate \\
\hline
\end{tabular}

This research was conducted in senior high school in Rokan Hulu, Riau, Indonesia. The study subjects were 63, included chemistry teachers and students of class XI SMA in Rokan Hulu, Riau, Indonesia. The sampling technique in this study is saturated sampling is the method of determining the sample if all members of the population are used as samples [46]. The data collection used expert validation questionnaires to determine the feasibility of the e-worksheet that has developed and essay test instruments used to measure critical thinking ability. While validation questionnaires data were analyzed using descriptive statistics, the reliability of the instrument was analyzed using statistics Cronbach alpha with the help of the SPSS 23 version and the improved teachers' critical thinking ability in this study was determined based on the average score gain normalized by Hake's criteria.

$$
\% \mathrm{~g}=\frac{\% \mathrm{Sf}-\% \mathrm{Si}}{100-\% \mathrm{Si}} \times 100 \%
$$

With:

$$
\begin{aligned}
& \mathrm{g}=\text { normalized gain } \\
& \mathrm{Sf}=\text { posttest score } \\
& \mathrm{Si}=\text { pretest score }
\end{aligned}
$$

The result of the calculation $<\mathrm{g}>$ value is then translated into 3 categories Hake [6] namely: 
Table 2. Gain value classification

\begin{tabular}{|l|l|}
\hline Average Gain & \multicolumn{1}{|c|}{ Criteria } \\
\hline $0.00<\mathrm{g} \leq 0.30$ & Low \\
\hline $0.30<\mathrm{g} \leq 0.70$ & Medium \\
\hline $0.70<\mathrm{g} \leq 1.00$ & High \\
\hline
\end{tabular}

The findings can be used to see students and teachers' critical thinking ability in thermochemistry content using evaluation sheets made with a 4 (four) Liker scale for positive statements: Very bad has a score of 1, not good at 2, and decent at a score of 3 , and very decent at 4 . For negative statements: very good with 4 points, not good with 3 points, decent with 2 points, and very good with 1 point [29]. And the categories can be seen in table 3 .

Table 3. Category Critical Thinking Ability

\begin{tabular}{|c|l|}
\hline Interval & \multicolumn{1}{|c|}{ Category } \\
\hline $75.1-100.0$ & Very good \\
\hline $50.1-75.0$ & Good \\
\hline $25.1-50.0$ & Not Good \\
\hline $0.0-25.0$ & Very Not Good \\
\hline
\end{tabular}

\section{$4 \quad$ Findings and Discussions}

\subsection{Findings}

In this study, researchers have applied four phases of the 4-D model, namely Define, Design, Develop, and Disseminate. To develop an e-worksheet using kvisoft flipbook maker software to improve teacher critical thinking ability it is obtained according to the following phases:

Define phase: The study process aimed at collecting detailed research-related knowledge. The expected activities of teaching and learning should adhere to the learning goals. A teacher should concentrate on using suitable approaches and media to increase students' critical thinking. In the context of chemistry learning media design based on e-worksheet using kvisoft flipbook maker, there are three key aspects to the theoretical process: student, instructor and teaching goals. The needs analysis of learning media, material and curriculum to determine the products needed and will be developed.

Needs analysis of learning media:

- Teachers find it still difficult to present abstract content, which is difficult to understand, one of which is thermochemistry material.

- Application of critical learning thinking is still minimal.

Thus, the learning media is one of the alternative solutions to the problem. The eworksheet learning media will aid teachers in learning and help students to apply critical thinking. 
Material analysis: The selection of this material based on the requirements found in class XI SMA in Rokan Hulu, Riau, Indonesia. The content is picked students required simple visualization of thermochemistry learning processes.

Curriculum analysis: The task analysis carried out was content structure analysis, namely, analyzing Basic Competence (BC), which was described as a learning indicator. Learning BC and learning indicators (LI) in thermochemistry materials are summarized in Table 4.

Table 4. BC and LI Applied in Learning Thermochemistry at Senior High School.

\begin{tabular}{|l|l|}
\hline \multicolumn{1}{|c|}{ Basic Competence (BC) } & \multicolumn{1}{|c|}{ Learning Indicator (LI) } \\
\hline $\begin{array}{l}\text { 1. Understanding the concept of } \Delta H \text { shows as reac- } \\
\text { tion heat at fixed pressure and its use in thermochem- } \\
\text { istry equations }\end{array}$ & $\begin{array}{l}\text { Differentiating systems and environments } \\
\text { Distinguishes reactions that release heat (exothermic) } \\
\text { 2. The use of thermochemistry equations combined } \\
\text { with changing number of reagents or reaction results that receive heat (endothermic) } \\
\text { Determining thermochemistry equations }\end{array}$ \\
$\begin{array}{l}\text { with changes in energy } \\
\text { Calculate the value of } \Delta H \text { through experiments with } \\
\text { a calorimeter }\end{array}$ \\
\hline $\begin{array}{l}\text { 3. Understand the various types of enthalpy reactions } \\
\text { (enthalpy of formation and enthalpy of combustion), } \\
\text { Hess's law, and the concept of bonding energy } \\
\text { 4. Determining enthalpy changes based on calorime- } \\
\text { try, enthalpy of formation, or bond energy based on } \\
\text { Hess's law }\end{array}$ & $\begin{array}{l}\text { Cescribe various standard enthalpy changes } \\
\text { Calculates the reaction enthalpy change } \\
\text { Calculates the average bond energy }\end{array}$ \\
\hline
\end{tabular}

Design phase: Based on the results of an informative discussion with a high school chemistry teacher in the Rokan Hulu Regency, an agreement was obtained to make an electronic worksheet (e-worksheet). This is because the chemistry teacher does not have the skills to make e-worksheets to improve students' critical thinking skills. This is in line with the 2013 curriculum that demands that students become familiar with critical thinking through the development of learning devices. According to learning theory, the thinking level of children aged 15-17 is a stage of formal (intellectual) operational development in which children can think, draw their conclusions, and interpret logically and critically. This is a consideration in drafting the e-worksheet concept. The results of this study are improvements to the activity sheet using the Kvisoft Flipbook Creator framework. Typically, printed activity sheets in Indonesia, particularly in learning activities. Researchers therefore created electronic activity sheets based on the flipbook creator software for students studying thermochemistry material. This study is renovated by converting printed teaching content to flip-book electronics from Kvisoft. The e-worksheet includes subjects, job processes, and evaluation methods, all focused on lesson study to train or improve teachers and students' critical thinking skills.

Develop phase: The student activity sheet on accessible thermochemistry material is then translated into a lesson study-based flipbook program. Experts verify the development of the e-worksheet for product validity, and the final result of the e-worksheet development phase is the blueprint for the next stage. The results of the e- worksheet validation can be seen in Table 5 . 
Paper-The Development of E-Worksheet Using Kvisoft Flipbook Maker Software Based on...

Table 5. The Results of Validation for E-Worksheet Based on Lesson Study Developed from Various Assessment Indicators

\begin{tabular}{|l|l|c|c|l|}
\hline No & \multicolumn{1}{|c|}{ Assessment indicators } & Average values & Score percentages $(\%)$ & \multicolumn{1}{|c|}{ Category } \\
\hline 1 & Feasibility of content & 3.84 & 95.93 & Very Decent \\
\hline 2 & Feasibility of language & 3.50 & 87.50 & Very Decent \\
\hline 3 & Feasibility of presentation & 3.63 & 90.83 & Very Decent \\
\hline 4 & Feasibility of graphic & 3.25 & 81.25 & Very Decent \\
\hline \multicolumn{2}{|l|}{ Average values } & $\mathbf{3 . 5 6}$ & $\mathbf{8 8 . 8 8}$ & Very Decent \\
\hline
\end{tabular}

From the results of the validation carried out by experts, it was found that the eworksheet valid category for content feasibility aspect of 95.39 , language feasibility aspect of 87.50 , presentation feasibility aspect of 90.83 , as well as graphic feasibility aspect of 81.25 . This showed that the e-worksheet using kvisoft flipbook maker software based on the lesson study is suitable for use in the chemistry learning process on the thermochemistry material. The validated e-worksheet is shown in the figure 1.

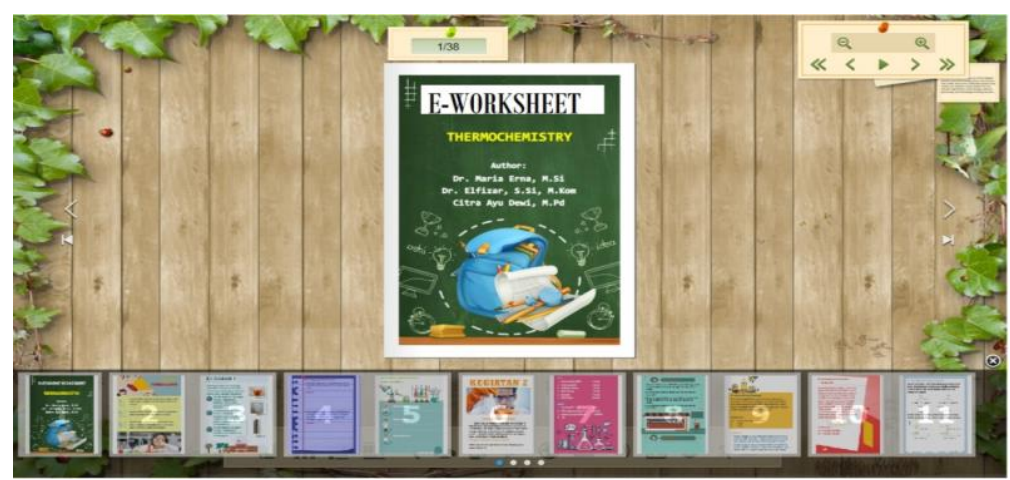

Fig. 1. E-Worksheet using kvisoft flipbook maker software

Disseminate phase: E-worksheets are applied simultaneously with the location and purpose of the prepared kvisoft flipbook maker programme, which encourage the awareness of chemistry on thermochemistry items so as to enable the system user use as well to enhance the understanding of material thermochemistry. The implementation using e-worksheet on thermochemistry material through lesson study was carried out as follows; the first Stage is conducting a Plan by preparing e-worksheets as a learning instrument adjusted to the curriculum 2013 validated by experts. The Second Stage was Do, the model teacher carries out chemistry learning using the developed e-worksheet, and the observer conducted classroom observations. The third Stage was reflection (Stage of see); the model teacher reflected the teaching had been performed. Furthermore, the observer team has concluded the learning reflection results to improve the learning quality and chemistry teacher's critical thinking ability. The instrument used to measure critical thinking ability is done trial to determine the reliability of the instrument. The reliability of critical thinking ability instrument used Cronbachs alpha value $>\mathrm{r}$ table (0.468), as shown in table 6. 
Table 6. Reliability of the critical thinking instrument

\begin{tabular}{|c|c|c|c|c|}
\hline Item & $\begin{array}{c}\text { Scale Mean if Item } \\
\text { Deleted }\end{array}$ & $\begin{array}{c}\text { Scale Variance if } \\
\text { Item Deleted }\end{array}$ & $\begin{array}{c}\text { Corrected Item-To- } \\
\text { tal Correlation }\end{array}$ & $\begin{array}{c}\text { Cronbach's Alpha } \\
\text { if Item Deleted }\end{array}$ \\
\hline 1 & 6.50 & 11.992 & 0.213 & 0.804 \\
\hline 2 & 6.47 & 11.466 & 0.395 & 0.791 \\
\hline 3 & 6.56 & 11.266 & 0.426 & 0.789 \\
\hline 4 & 6.63 & 11.745 & 0.269 & 0.801 \\
\hline 5 & 6.60 & 10.868 & 0.548 & 0.779 \\
\hline 6 & 6.42 & 11.067 & 0.566 & 0.779 \\
\hline 7 & 6.50 & 10.779 & 0.612 & 0.775 \\
\hline 8 & 6.50 & 10.680 & 0.647 & 0.772 \\
\hline 9 & 6.98 & 12.311 & 0.172 & 0.804 \\
\hline 10 & 7.15 & 12.684 & 0.248 & 0.800 \\
\hline 11 & 7.16 & 12.924 & 0.000 & 0.804 \\
\hline 12 & 7.03 & 12.163 & 0.275 & 0.798 \\
\hline 13 & 6.76 & 11.531 & 0.342 & 0.795 \\
\hline 14 & 6.97 & 12.196 & 0.205 & 0.802 \\
\hline 15 & 6.63 & 10.762 & 0.579 & 0.777 \\
\hline 16 & 6.69 & 10.675 & 0.607 & 0.774 \\
\hline 17 & 7.05 & 11.981 & 0.381 & 0.792 \\
\hline 18 & 7.15 & 12.847 & 0.067 & 0.804 \\
\hline
\end{tabular}

Based on table 6 , showed that the reliability value of 18 items was $>0.468$ with very high criteria. The results of the development of teacher professional competencies can be seen from the value of percentage of teachers critical thinking ability indicators in Table 7.

Table 7. Percentage of Teachers Critical Thinking Ability Indicators

\begin{tabular}{|c|l|c|l|}
\hline No & \multicolumn{1}{|c|}{ Critical Thinking Ability Indicator } & Percentage (\%) & \multicolumn{1}{c|}{ Category } \\
\hline 1 & Classifying & 75 & Good \\
\hline 2 & Assuming & 66 & Good \\
\hline 3 & Predicting and hypothesizing & 77 & Good \\
\hline 4 & Interpreting data, differentiating or making conclusions & 61 & Good \\
\hline 5 & Measuring & 61 & Good \\
\hline 6 & Designing an investigation to solve the problem & 65 & Good \\
\hline 7 & Analyzing & 60 & Good \\
\hline
\end{tabular}

Based on the results shown at table 7, teachers' critical thinking ability with good category. This can be seen from, critical thinking ability indicators percentages reported. For teacher classifying was $75 \%$; assuming was $66 \%$; predicting and hypothesizing was $77 \%$; interpreting data, differentiating or making conclusions was $61 \%$; measuring was $61 \%$; designing an investigation to solve the problem was $65 \%$; analyzing was $60 \%$. In contrast, the percentage of student's critical thinking ability indicators in the Rokan Hulu district can be seen in Table 8 . 
Table 8. Percentage of Students' Critical Thinking Ability Indicators

\begin{tabular}{|c|l|c|l|}
\hline No & \multicolumn{1}{|c|}{ Critical Thinking Ability Indicator } & $\begin{array}{c}\text { Percentage } \\
(\%)\end{array}$ & Category \\
\hline 1 & Classifying & 78 & Good \\
\hline 2 & Assuming & 75 & Good \\
\hline 3 & Predicting and hypothesizing & 66 & Good \\
\hline 4 & Interpreting data, differentiating or making conclusions & 61 & Good \\
\hline 5 & Measuring & 63 & Good \\
\hline 6 & Designing an investigation to solve the problem & 68 & Good \\
\hline 7 & Analyzing & 64 & Good \\
\hline
\end{tabular}

Based on table 8, students' critical thinking ability with good category. This can be seen from, critical thinking ability indicators percentages reported. For students classifying was 78\%; assuming was $75 \%$; predicting and hypothesizing was $66 \%$; interpreting data, differentiating or making conclusions was $61 \%$; measuring was $63 \%$; designing an investigation to solve the problem was $68 \%$; analyzing was $64 \%$. The category of students' critical thinking ability on thermochemistry as shown in table 9.

Table 9. The Category of Students' Critical Thinking Ability on Thermochemistry

\begin{tabular}{|c|c|c|l|}
\hline No & Cycle in Lesson Study & Average of test values & Category of Critical Thinking \\
\hline 1 & I & 63 & Good \\
\hline 2 & II & 78 & Good \\
\hline 3 & III & 83 & Very Good \\
\hline
\end{tabular}

Based on the results shown at table 9, students' critical thinking ability increasedfrom cycle I until cycle III. The cycle I was 63 with good category, the cycle II increased to 78 with good category, and the cycle III increased to 83 with a very good category. While the category of teachers' critical thinking ability as shown in table 10 .

Table 10. The Category of Teachers' Critical Thinking Ability

\begin{tabular}{|c|c|c|l|}
\hline No & Cycle in Lesson Study & Average of test values & Category of Critical Thinking \\
\hline 1 & I & 49 & Not Good \\
\hline 2 & II & 57 & Good \\
\hline 3 & III & 60 & Good \\
\hline
\end{tabular}

Based on table 10, teachers' critical thinking ability increased from cycle I until cycle III. The cycle I was 49 with not good category, the cycle II increased to 57 with good category, and the cycle III increased to 60 with good category.

\subsection{Discussions}

The data analysis results showed that critical thinking ability for all indicators increased after implementation e-worksheet using kvisoft flipbook maker software based on lesson study. Therefore, from that research, we can safely say that the e-worksheet based on lesson study is effective for improving critical thinkingability of teachers' and 
students. However, the results of the study also show that the increase in indicators (interpreting data, differentiating or making conclusions; measuring; analyzing) is still at low category compared with other indicators (classifying; assuming; predicting and hypothesizing; and designing an investigation to solve the problem). This is because original/unique/new thinking is the essence of critical thinking. This statement is in line with Rosidin et al. [47] stated that critical thinking is a mental mechanism in the world defined by current knowledge. Critical thinking is an important character student must process. This character has to be identified and followed in a university's character education [48]. Critical thinking skills are a background of $21^{\text {st }}$ century skills in which these skills prepare students with logic and argumentation in presenting arguments for hypotheses or conclusions gained [49].

The reason why the e-worksheet based on lesson study was effective in increase critical thinking ability of teachers and students because critical thinking can be done in several ways (1) trained to analyze arguments, (2) starting from identifying conclusions, (3) identifying reasons, (4) looking for similarities and differences, (5) identifying and dealing, (6) searched for structural arguments and (7) summarize. Its whole activities were indicators of critical thinking ability [47]. Other than, the e-worksheet describes phenomena that are concrete, simple, and related to the concepts to study and invites students to reconstruct their knowledge [4]. This e-worksheet is designed to guide learning activities, save time, optimize teaching aids, help students actively engage in learning, improve students' ability to solve problems, and improve critical thinking skills [29].

In the classroom implementation, Lesson study involves learning groups with small members. The main purpose of small group learning is to simulate a realistic teambased work environment. Another goal is to foster community practices that will provide group members with (1) opportunities for reciprocal involvement, (2) joint efforts, and (3) joint repertoires. Lesson study implementation can be done through 3 steps namely 1) Plan, open lesson stage is carried out through the learning process, which a teacher is used as a model and the other teacher acts as an observer. 2) Do, the teacher performs apperception and motivation to focus students' attention, then the monitors group activities and guides student activities. 3) See, the results of the open class are reflected by the learning community team by discussing after the learning process. The E-Worksheet follows the Lesson Study with 3 steps are Plan, Do, see after that at each step taken is given a stimulus to increase critical thinking. Because Lesson Study is a learning that puts forward problem solving or finding various solutions to a problem, while critical thinking is related to analytical activities to determine actions [4].

Some recent research has been effective in improving critical thinking ability for colleges and teachers through e-worksheets using kvisoft flipbook [28] [29] [30] [32] [34] [36] pre-service teachers [43], and students [44] [45] [50]. Critical thinking was not significantly different among students using the career-oriented challenge model and conventional learning [18]. Resources of other research show that critical thinking skills among treatment groups have improved considerably compared to control groups, such as using the micro-teaching model [43], online-based problem delivery [40] and inquiry-based learning [45]. Whereas in this study, e-worksheet-based lesson study provided innovation in chemistry learning. Other studies have extensively discussed the 
investigation of a pre-service elementary school teacher in the use of worksheets on the subject of science and technology [37]. Several scientific models have published using worksheets on various topic such as; changing physical and chemistry events, the topic of chemistry compound to improve student achievement, material science process to regain their scientific process skills [38] [39]. This work aimed at examining e-worksheets based on lesson analysis, to improve the critical thinking capabilities of teachers. Zhou et al. [16] proposed that task-based learning can improve students' critical thinking skills in chemistry experiments. In this study, many samples were significantly involved and found significant differences in student learning outcomes in the pre-test and post-test sessions ( $\mathrm{p}<0.05$ ). Qing et al. [17] proposed the development of inquirybased critical thinking skills implemented in chemistry teachers. This study has successfully demonstrated that the inquiry model can improve teachers' critical thinking skills, but this study only involved a small sample size (42 people). Other studies were also focused on improving the thinking skills of students and teachers in the learning process. For instance, career-based assignment models [18], micro-learning [43], android-based learning [44], problem-based online learning [40], metacognitive strategies [41], inquiry-based learning [45] have been reported.

\section{Conclusion}

Based on the results obtained from this study, it can be concluded that the development of e-worksheets using kvisoft flipbook maker software based on lesson study is feasibility for use in the teaching and learning process on thermochemistry material and can improve the critical thinking ability of teachers and students. The critical thinking ability indicators percentage given at recapitulation report is evident for this conclusion. For teacher classifying was $75 \%$; assuming was $66 \%$; predicting and hypothesizing was $77 \%$; interpreting data, differentiating or making conclusions was $61 \%$; measuring was $61 \%$; designing an investigation to solve the problem was $65 \%$; analyzing was $60 \%$. While for students classifying was $78 \%$; assuming was $75 \%$; predicting and hypothesizing was 66\%; interpreting data, differentiating or making conclusions was $61 \%$; measuring was $63 \%$; designing an investigation to solve the problem was $68 \%$; analyzing was $64 \%$. This research implies that the development of e-worksheet using kvisoft flipbook maker software based on lesson study is one good option for improving critical thinking ability of teachers' and students' because it's simple for students to learn using e-worksheets using gadgets. Explanations using devices are more reliable, more interesting, more convenient to bring, and more information before learning. Thus, support teachers in learning activities and communicating information in learning. This e-worksheet can be applied in different fields of education. Future research on the same subject should be performed in various topics and contexts.

\section{Acknowledgement}

Thanks to the Research Institute of Universitas Riau that has founded this research. 


\section{$7 \quad$ References}

[1] Martyanti, A., \& Suhartini, S. (2018). Etnomatematika: Menumbuhkan Kemampuan Berpikir Kritis Melalui Budaya Dan Matematika. IndoMath: Indonesia Mathematics Education, 1(1), 35-41. https://doi.org/10.30738/indomath.v1i1.2212

[2] Nold, H. (2017). Using Critical Thinking Teaching Methods to Increase Student Success: An Action Research Project. International Journal of teaching and learning in Higher Education, 29(1), 17-32.

[3] Mulnix, J. W. (2012). Thinking critically about critical thinking. Educational Philosophy and theory, 44(5), 464-479. https://doi.org/10.1111/j.1469-5812.2010.00673.x

[4] Sujatmika, S., Irfan, M., Ernawati, T., Wijayanti, A., Widodo, S. A., Amalia, A. F., \& Rahim, R. (2019). Designing E-Worksheet Based on Problem-Based Learning to Improve Critical Thinking. ICSTI, October 19-20, Yogyakarta, Indonesia. https://doi.org/10.4108/eai. 19-10-2018.2281282

[5] Dewi, C. A. (2019). Improving creativity of prospective chemistry teacher through chemoEntrepreneurship oriented inquiry module on colloid topics. Journal of Physics: Conference Series (Vol. 1156, No. 1, p. 012017). IOP Publishing. https://doi.org/10.1088/1742$\underline{6596 / 1156 / 1 / 012017}$

[6] Dewi, C. A., \& Mashami, R. A. (2019). The Effect of Chemo-Entrepreneurship Oriented Inquiry Module on Improving Students' Creative Thinking Ability. Journal of Turkish Science Education, 16(2), 253-263.

[7] Birjandi, P., \& Bagherkazemi, M. (2010). The Relationship between Iranian EFL Teachers' Critical Thinking Ability and Their Professional Success. English language teaching, 3(2), 135-145. https://doi.org/10.5539/elt.v3n2p135

[8] Howard, P. G. (2018). Twenty-First Century Learning as a Radical Re-Thinking of Education in the Service of Life. Education Sciences, 8(189), 1-13. https://doi.org/10.3390/ educsci8040189

[9] Howard, S. J., Siraj, I., Melhuish, E. C., Kingston, D., Neilsen-Hewett, C., de Rosnay, M., \& Luu, B. (2018). Measuring interactional quality in pre-school settings: introduction and validation of the Sustained Shared Thinking and Emotional Wellbeing (SSTEW) scale. Early Child Development and Care, 1-14. https://doi.org/10.1080/03004430.2018. 1511549

[10] Lai, E. R. (2011). Critical thinking: A literature review. Pearson's Research Reports, 6, 4041.

[11] Sadhu, S., Ad'hiya, E., \& Laksono, E. W. (2019). Exploring and Comparing Content Validity and Assumptions of Modern Theory of an Integrated Assessment: Critical ThinkingChemical Literacy Studies. Journal Pendidikan IPA Indonesia, 8(4), 570-581. https://doi.org/10.15294/jpii.v8i4.20967

[12] Fuad, N. M., Zubaidah, S., Mahanal, S., \& Suarsini, E. (2017). Improving Junior High Schools' Critical Thinking Skills Based on Test Three Different Models of Learning. International Journal of Instruction, 10(1), 101-116. https://doi.org/10.12973/iji.2017. $\underline{1017 \mathrm{a}}$

[13] Kim, K., Sharma, P., Land, S. M., \& Furlong, K. P. (2013). Effects of active learning on enhancing student critical thinking in an undergraduate general science course. Innovative Higher Education, 38(3), 223-235. https://doi.org/10.1007/s10755-012-9236-x

[14] Nold, H. (2017). Using Critical Thinking Teaching Methods to Increase Student Success: An Action Research Project. International Journal of teaching and learning in Higher Education, 29(1), 17-32. 
[15] Zhou, Q., Huang, H. \& Tian. (2013). Developing students' critical thinking skills by taskbased learning in chemistry experiment teaching. Creative Education, 4(12A), 40-45. https://doi.org/10.4236/ce.2013.412a1006

[16] Qing, Z., Jing, G \& Yan, W. (2010). Promoting preservice teachers' critical thinking skills by inquiry-based chemistry experiment. Procedia Social and Behavioral Sciences 2 (2010) 4597-4603. https://doi.org/10.1016/j.sbspro.2010.03.737

[17] Espinosa, A.A., Monterola, S.L.C. \& Punzalan, A. E. (2013). Career-oriented performance tasks in chemistry: effects on students' critical thinking skills. Education Research International, 2013: 1-10. https://doi.org/10.1155/2013/834584

[18] Doig, B. \& Groves, S. (2011). Japanese Lesson study; Teacher professional development through communities of inquiry. Mathematics Teacher Education and Development, 13(1), 77-93.

[19] Fadillah, A., Dewi, N.P.L. C., Ridho, D., Majid, A.N \& Prastiwi, M.N.B. (2017). The effect of application of contextual teaching and learning (CTL) model-based on lesson study with mind mapping media to assess student learning outcomes on chemistry on colloid systems. International Journal of Science and Applied Science: Conference Series, 1(2), 101-108. https://doi.org/10.20961/ijsascs.v1i2.5128

[20] Halim, N.D.A., Bakar, E.E.A., Mokhtar, M., Abdullah, A.H., Surif, J., Ali, D.F., Ali, M., Suhairom, N.B \& Jumaat, N. F. (2017). The effects of cooperative learning activities in blossoms lesson towards students' achievement in learning chemistry. Man, In India, 97(19), 323-329.

[21] Lucenario, J.L.S., Yangco, R.T., Punzalan, A.E \& Espinosa, A.A. (2016). Pedagogical Content Knowledge-Guided Lesson Study: Effects on Teacher Competence and Students' Achievement in Chemistry. Education Research International, 2016, 1-9. https://doi.org/10.1155/2016/6068930

[22] Zhou, G., Xu,J. \& Martinovic, D. (2017). Developing pre-service teachers' capacity in teaching science with technology through microteaching lesson study approach. EURASIA Journal of Mathematics Science and Technology Education, 13 (1), 85-103. https://doi.org/10.12973/eurasia.2017.00605a

[23] Bahçivan, E. (2017). Implementing Microteaching Lesson Study with a Group of Preservice Science Teachers: An Encouraging Attempt of Action Research. International Online Journal of Educational Sciences. 9(3), 591- 602. https://doi.org/10.15345/iojes.2017. $\underline{03.001}$

[24] Kıncal, R.Y., Yazgan, A.D \& Kartal, O. Y. (2016). The Effect of Lesson Study Approach upon Critical Thinking Skills Development: An Investigation into Arabic Language Preservice Teachers. E-Learn: 406-414.

[25] Lomibao, L.S. (2016). Enhancing mathematics teachers' quality through Lesson Study. Springer Plus, 5(1590),1-13.

[26] Sabang, S.M \& Suherman. (2017). Lesson Study as a Comprehensive Learning Strategy to Build Students' Character. Advances in Social Science, Education and Humanities Research174, 352-355. https://doi.org/10.2991/ice-17.2018.75

[27] Riyadi, B., Ertikanto, C., \& Suyatna, A. (2018). The analysis and design of guided inquiry e-worksheet Based to develop high order thinking skills. International Journal of ResearchGranthaalayah, 6(7), 223-233. https://doi.org/10.29121/granthaalayah.v6.i7.2018.1302

[28] Asrial, H., \& Ernawati, M. (2020). E-Worksheet for Science Processing Skills Using Kvisoft Flipbook. International Journal of Online \& Biomedical Engineering, 16(3), 46-59. https://doi.org/10.3991/ijoe.v16i03.12381

[29] Arifin, H. R. (2014). Developing English Interactive Multimedia Students' E-Worksheet for Fourth Graders of Elementary School. Vol. Ix, No. October, 73-83. 
[30] Choo, S. S., Rotgans, J. I., Yew, E. H., \& Schmidt, H. G. (2011). Effect of worksheet scaffolds on student learning in problem-based learning. Advances in health sciences education, 16(4), 517. https://doi.org/10.1007/s10459-011-9288-1

[31] Haryanto, H., Asrial, A., \& Ernawati, M. D. W. (2020). E-Worksheet for Science Processing Skills Using Kvisoft Flipbook. International Journal of Online and Biomedical Engineering (iJOE), 16(03), 46-59. https://doi.org/10.3991/ijoe.v16i03.12381

[32] Ningrum, M. V., Abdullah, R., \& Nasution, V. Y. (2019). Preliminary study in the student worksheet development using inquiry-based learning model with science process skills approach for physics learning of second grade high school. In Journal of Physics: Conference Series (Vol. 1317, No. 1, p. 012163). IOP Publishing. https://doi.org/10.1088/17426596/1317/1/012163

[33] Irwansyah, F. S., Lubab, I., Ramdhani, I. F. M. A., \& Farida, I. (2017). Designing interactive electronic module in chemistry lessons. In Journal of Physics: Conference Series (Vol. 895, No. 1, p. 012009). IOP Publishing. https://doi.org/10.1088/1742-6596/895/1/012009

[34] Atasoy, Ş., \&Ergin, S. (2017). The effect of concept cartoon-embedded worksheets on grade 9 students' conceptual understanding of Newton's laws of motion. Research in Science \& Technological Education, 35(1), 58-73. https://doi.org/10.1080/02635143.2016. $\underline{1248926}$

[35] Y1ldırım, N., Kurt, S., \&Ayas, A. (2011). The effect of the worksheets on students' achievement in chemical equilibrium. Journal of Turkish Science Education, 8(3), 44-58.

[36] Oren, F.S. \&Ormaci, U. (2012). An Application about Pre-Service Teachers' Development and Use of Worksheets and an Evaluation of their Opinions about the Application. Educational Sciences: Theory \& Practice, 12(1), 263-270.

[37] Kibar, Z. B \&Ayas, A. (2010a). Developing a worksheet about physical and chemistry event. Procedia Social and Behavioral Sciences, 2(2010), 739-743. https://doi.org/10.1016/j. sbspro.2010.03.094

[38] Kibar, Z. B \&Ayas, A. (2010b). Implementing of a worksheet related to physical and chemistry change concepts. Procedia Social and Behavioral Sciences, 2 (2010), 733-738. https://doi.org/10.1016/j.sbspro.2010.03.093

[39] Sendaq, S \& Odabasi, H.F. (2009). Effect of an online problem-based learning course on content knowledge acquisition and critical thinking skills. Computer and Education, 53, 132-141. https://doi.org/10.1016/j.compedu.2009.01.008

[40] Ku, K. Y. L \& Ho, I. T. (2010). Metacognitive strategies that enhance critical thinking. Metacognition Learning, 5. 251-267. https://doi.org/10.1007/s11409-010-9060-6

[41] Erna, M., Rasmiwetti, Adnan, E. \&Wahyudi, V. (2019). Effectiveness of solubility equilibrium module based on lesson study to improve critical thinking ability of chemistry students and teachers in senior high school Kampar district, Riau. Journal of Physics: Conference Series (Vol. 1321, No. 2, p. 022044). IOP Publishing. https://doi.org/10.1088/1742$\underline{6596 / 1321 / 2 / 022044}$

[42] Arsal, Z. (2015). The effects of microteaching on the critical thinking dispositions of preservice teachers. Australian Journal of Teacher Education, 40(3), 140-149. https://doi.org/10.14221/ajte.2014v40n3.9

[43] Wardani, S., Lindawati, L. \& Kusuma, S.B.W. (2017). The development of inquiry by using android-system-based chemistry board game to improve learning outcome and critical thinking ability. Jurnal Pendidikan IPA Indonesia, 6(2), 196-205. https://doi.org/10.15294/ jpii.v6i2.8360

[44] Duran, M. (2016). The effect of the inquiry-based learning approach on student's criticalthinking skills. Eurasia Journal of Mathematics, Science \& Technology Education, 12(12), 2887-2908. https://doi.org/10.12973/eurasia.2016.02311a 
[45] Sugiyono, P. (2013). Metode Penelitian Kuantitatif, Kualitatif, dan R\&D. Bandung: CV Alfabeta.

[46] Rosidin, U., Suyanta, A., \& Abdurrahman, A. (2019). A combined hots-based assessment/stem learning model to improve secondary students' thinking skills: a development and evaluation study. Journal for the Education of Gifted Young Scientists, 7(3), 435-448. https://doi.org/10.17478/jegys.518464

[47] Kurjum, M., Muhid, A. \&Thohir, M. (2019). Think Pair Share Model as Solution to Develop Students Critical Thinking in Islamic Studies: is it Effective? Cakrawala Pendidikan, 39(1), 144-155. https://doi.org/10.21831/cp.v39i1.28762

[48] OECD. (2018). PISA 2015: Results infocus. Retrieved from https://www.oecd.org/.

[49] Mulhem, A. (2020). Exploring the Key Factors in the Use of an E-Learning System among Students at King Faisal University, Saudi Arabia.

[50] Sumarwati, S., Fitriyani, H., Setiaji, F. M. A., Amiruddin, M. H., \& Jalil, S. A. (2020). Developing Mathematics Learning Media Based on E-Learning using Moodle on Geometry Subject to Improve Students' Higher Order Thinking Skills. International Journal of Interactive Mobile Technologies (iJIM), 14(04), 182-191. https://doi.org/10.3991/ijim. v14i04.12731

[51] Anshari, M., Alas, Y. \& Guan, L. S. (2016). Developing Online Learning Resources: Big Fata, Social Network, and Cloud Computing to Support Pervasive Knowledge. Education and Information Technologies, 21(6), 1663-1677. https://doi.org/10.1007/s10639-015$\underline{9407-3}$

[52] Fahmi, S., Priwantoro, S. W., Cahdriyana, R. A., Hendroanto, A., Rohmah, S. N \& Nisa, L. C. (2019). Interactive Learning Media Using Kvisoft Flipbook Maker for Mathematics Learning, Journal of Physics: Conf. Series, 1188. https://doi.org/10.1088/1742$\underline{6596 / 1188 / 1 / 012075}$

[53] Darmaji, D., Kurniawan, D. A., Astalini, A., Lumbantoruan, A. \& Samosir, S. C. (2019). Mobile Learning in Higher Education for the Industrial Evolution 4.0: Perception and Response of Physics Practicum, International Journal of Interative Mobile (IJIM), 13(9), 4-20. https://doi.org/10.3991/ijim.v13i09.10948

[54] Astalini, A., Darmaji, D., Kurniawan, D. A. \& Melsayanti, R. (2019). E-Assessment of Student Perception of Natural Science Based on Seska in Middle School Students in Indonesia. International Journal of Scientific \& Technology Research, 8(9), 858-863.

[55] Fonda, A \&Sumargi. (2018). The Developing Math Electronic Module with Scientific Approach Using Kvisoft Flipbook Maker Pro for XI Grade of Senior High School Students. Journal of Mathematics Education, 7(2), 109-122.https://doi.org/10.22460/infinity.v7i2. p109-122

[56] Wibowo, E. \& Pratiwi, D. (2018). Pengambangan Bahan Ajar Menggunakan Aplikasi Kvisoft Flipbook Maker Materi Himpunan. Desimal: JurnalMatematika, 1 (2), 147-156. https://doi.org/10.24042/djm.v1i2.2279

[57] Papadakis, S., Kalogiannakis, M., \& Zaranis, N. (2018). The effectiveness of computer and tablet assisted intervention in early childhood students' understanding of numbers. An empirical study conducted in Greece. Education and Information Technologies, 23(5), 18491871. https://doi.org/10.1007/s10639-018-9693-7

[58] Papadakis, S., \& Kalogiannakis, M. (2017). Mobile educational applications for children: what educators and parents need to know. International Journal of Mobile Learning and Organisation, 11(3), 256-277. https://doi.org/10.1504/ijmlo.2017.085338

[59] Kalogiannakis, M., \& Papadakis, S. (2017). Combining mobile technologies in environmental education: a Greek case study. International Journal of Mobile Learning and Organization, 11(2), 108-130. https://doi.org/10.1504/ijmlo.2017.10005249 
[60] Kalogiannakis, M., Nirgianaki, G. M., \& Papadakis, S. (2018). Teaching magnetism to preschool children: The effectiveness of picture story reading. Early Childhood Education Journal, 46(5), 535-546. https://doi.org/10.1007/s10643-017-0884-4

[61] Papadakis, S., Kalogiannakis, M., \& Zaranis, N. (2016). Developing fundamental programming concepts and computational thinking with Scratch Jr in preschool education: a case study. International Journal of Mobile Learning and Organization, 10(3), 187-202. https://doi.org/10.1504/ijmlo.2016.077867

[62] Lewis, C. C., Perry, R. R., Friedkin, S., \& Roth, J. R. (2012). Improving teaching does improve teachers: Evidence from lesson study. Journal of teacher education, 63(5), 368-375. https://doi.org/10.1177/0022487112446633

[63] Fernandez, M. L. (2010). Investigating how and what prospective teachers learn through microteaching lesson study. Teaching and Teacher Education, 26(2), 351-362. https://doi.org/10.1016/i.tate.2009.09.012

[64] Coenders, F., \& Verhoef, N. (2019). Lesson study: professional development (PD) for beginning and experienced teachers. Professional development in education, 45(2), 217-230. https://doi.org/10.1080/19415257.2018.1430050

[65] Burroughs, E. A., \& Luebeck, J. L. (2010). Pre-service teachers in mathematics lesson study. The Mathematics Enthusiast, 7(2), 391-400.

\section{Authors}

Maria Erna was born in Dalu-Dalu Riau, Indonesia, in 1972. She is an Associate Professor at the Department of Chemistry Education, Universitas Riau, Pekanbaru, Indonesia, Postcode 28293. Her research interest is focused on developing learning media based on lesson study as a learning community and application of Information and Communication, Technology (ICT) to chemistry learning. She has published articles in national and international journals. ORCID iD: 0000-0001-5644-7598 email: mariaerna@lecturer.unri.ac.id

Elfizar is an Associate Professor at the Information System Department, Universitas Riau, Pekanbaru, Indonesia, Postcode 28293. He graduated Ph.D in Distributed Systems at Artificial Intelligence Department, University of Malaya, Malaysia. His research interest is in Artificial Intelligence, Image Processing, Distributed Virtual Environment, and Smart Media. He has published some papers indexed by Web of Science and Scopus. His current project is 3D Application for Malay artifacts and The Implementation of Smart Media in Learning email: elfizarmd@gmail.com.

Citra Ayu Dewi is a senior lecturer in the Chemistry Education Department of Applied Science and Technique Faculty of Universitas Pendidikan Mandalika, Mataram, Indonesia, Jln. Pemuda 59A, Postcode 83125. She obtained his master's degree from Universitas Negeri Malang. Her research interest includes: developing model and media of learning, computer and internet-based learning, STEM-based learning, and applied chemistry. ORCID: 0000-0001-9381-9645. She is the Editor-in-Chief of the journal hydrogen email: ayudewi citra@ikipmataram.ac.id.

Article submitted 2020-05-21. Resubmitted 2020-09-26. Final acceptance 2020-09-27. Final version published as submitted by the authors. 